\title{
Traditional Internship Pattern in Developing Community Enterpreneurship
}

\author{
Mustakim \\ Department of Non-Formal Education \\ Univeristas Pendidikan Indonesia \\ Bandung, Indonesia \\ mustakimpls@student.upi.edu
}

\begin{abstract}
The problem of unemployment and poverty is a common problem faced by developing countries, especially Indonesia. The number of unemployed is growing from year to year. In February 2016, the number of unemployed was recorded around 7.02 million people. This condition if constantly left unchecked, it will have an impact on the community's economy. Through traditional internship pattern expected the community's economy can improve. The purpose of this study was to determine the implementation of traditional internship pattern, to increase entrepreneurial community and to know the advantages and disadvantages of the pattern of traditional apprenticeship itself. Author is interested in researching traditional internship pattern because traditional internship pattern is a method of learning work in which taught from generation to generation. Moreover, the traditional internship pattern is an effort to transform the skills, knowledge, and attitudes within the family, community, and environment. This study uses descriptive research with qualitative research approaches. The result of this study has a positive impact in improving the entrepreneurial community as well as improving skills, knowledge, and mental attitudes in community entrepreneurship.
\end{abstract}

Keywords-Unemployment, Traditional Internship Pattern, Entrepreneurial Community.

\section{INTRODUCTION}

The quality of human resources is a determining factor in the development of a nation. Qualified human resource is the main capital in development. Indonesia is a country rich in human resources but the unemployment rate is increasing year after year. In February 2016, unemployment in Indonesia reached 7.02 million people [1].

Through education expected increase in knowledge and skills. Education and skills used as a tool improving human resource like adults in improving human resources in various ways such as through courses and training. Courses and training is organized for people who need a stock of knowledge, skills, life skills, attitudes to develop themselves, to develop the profession, to work, an independent business, and/or continuing education to a higher level [2].

Probolinggo regency in Indonesia is one of the districts with relatively high illiteracy rates when compared with other regions. The number of illiterates reached 81.749 people [3]. This condition is due to the many young marriages in which the young age marriage ended in divorce, and dropouts. This is due to the lack of educational facilities, access roads far away from the city, and the lack of government support in improving the welfare the community. Probolinggo is located on a mountain slope that stretches from West to East among the Tengger mountain, Lamongan mountain and Argopuro mountain. The total area of Probolinggo is approximately $1696.16 \mathrm{sq} . \mathrm{km}$ in which consists of settlements $\left(147.74 \mathrm{~km}^{2}\right)$, rice fields $\left(373.13 \mathrm{~km}^{2}\right)$, tegals $\left(513.80 \mathrm{~km}^{2}\right)$, plantations $(32.81$ $\mathrm{km}^{2}$ ) forests $\left(426.46 \mathrm{~km}^{2}\right)$, ponds $\left(13.99 \mathrm{~km}^{2}\right)$, and the others $\left(188.23 \mathrm{~km}^{2}\right)$ [4].

With the condition the majority of the rice fields, flanked by mountains, and fewer jobs cause the unemployment rate from year to year increasing. In addition to high crime, many children drop out of school due to economic pressures. So, that people will prefer to work rather than continue their education to a higher level. To overcome these problems are needed job training. Job training is an activity to give, gain boost, develop job competence, discipline and work ethic at the level of skill and expertise in accordance with the level and qualification of position or employment [5].

Education and skills is one of the measures to reduce the problems in the community. If we look at the Germany, that"...German apprentices acquire specific skills through training program sat firms"'[6]. Unlike in Indonesia, to gain the skills the community should make a program or join a training institute.

Because the social conditions of the Indonesian people in below average then the program required in accordance with the needs of the community such as a confection business. The reasons for selecting confection business due to Probolinggo is district in early stages of development. Construction of government buildings and schools from kindergarten to high school formal in one complex, in the Kraksaan district, make the need for school uniforms, work uniforms and daily wear increasing. While investors have not yet intensively handle those needs.

\section{METHOD}

Researcher used descriptive research method with qualitative research approaches. Qualitative research is a study that indicated to describe and analyze the phenomena, events, social activities, attitudes, beliefs, perceptions, thoughts of 
people as well as individuals or groups [7]. Techniques used in data collection is by interview, observation and documentation [8]. Researcher used data validity criteria is to support that this study has a credibility, transferability, dependability and confirmability [9].

\section{RESULT AND DISCUSSION}

Implementation traditional internship pattern on a confection business in terms of four aspects are: a) identification of the type of skills, b) the implementation phase, c) the internships assessment phase, and d) follow-up of apprenticeship.

Identify the type of skills is an early stage in the determination of the internship program in accordance with the needs of internship participants. At this stage, will be held recruiting of internship participants in accordance with the field of sewing skills. Recruitment of internship participants aged between 18-45 years. Recruitment of internship participants aged between 18-45 years with minimal education junior high school and from low income families. The results of the recruitment of internship participants as many as three internship participants namely Z. Andrianto (28 years), Siti Halimah (36 years) and Ali Wafa (32 years). The recruitment process in line with the opinion of Sudjana that, "in the recruitment of trainees which includes registration and selection of participants. Registration and reception of participants based on predetermined criteria and be adapted to needs, quality and carrying capacity available" [10].

From the result of the recruitment of internship participants then is held the formulating objectives and the internship teaching materials. The purpose of apprentice is for participants to acquire knowledge of sewing, sewing skills, raising mental attitude entrepreneurship, and increasing business insight in a field of confection. The above statement in accordance with the opinion of Sudjana in which learning purpose is a statement about the acquisition of learning to be achieved learners through learning. The learning acquisition can be the knowledge, skills and values that become part of the lives of learners [11].

Internship teaching materials adjusted by the needs of internship participants. Internship teaching materials are adjusted by to the needs of internship participants including how to operate the sewing machine, cut the shirt and pants, sew short and long trousers, sew a pocket, collar, and attach the buttons. This is in accordance with the identification of learning needs in which identification of learning needs is seeking activities, finding, recording and managing data on the learning needs of the desired or expected by a trainee or organization [12].

While at the implementation stage, the internship activities carried out by the Sanggar Kegiatan Belajar Krasaan in Probolinggo district. At this stage, the learning using participatory methods and demonstrations. The facilitator emphasizes practical lesson than on theory with a composition of $80 \%$ on practice and $20 \%$ on theory. Through participatory learning approach, internship participants became more active in the following study. So, that internship participants can decide sewing skills which according to their needs. A participatory process does not necessarily mean that every stakeholder will participate in every phase of the decision process [13].

Time allocation is the result of a learning contract. Because the internship participants with the facilitator should agree on a time of learning. So, the allocation of apprenticeship carried on for 2 months with one formal meeting every Saturday and informal meetings in accordance with the needs of internship participants. Apprentice participants are given freedom to spend time learning in the place of internship. The apprenticeship pathway as primarily performed at workplaces seems to refer to time spent at the workplace, rather than educational content or learning aims [14].

The fund of internship is cost which used for learning activities apprenticeship. All fees are taken from the budget program of the Sanggar Kegiatan Belajar Kraksaan in Probolinggo district. During the apprenticeship, internship participants receive operating funds amounting to Rp. 500,000, - (five hundred thousand rupiah) per group. These funds are used for venture capital post-internship. These business funds are as morale boosters or extrinsic motivation for internship participants to establish a new confection business in each his house. "...extrinsic motivation is defined as the motivation to work primarily in response to the receipt of external rewards, such as money or position status or a work vehicle" [15].

The place of internship at Mrs. Kholifah (facilitator). The apprenticeship place covers approximately seven square meters $\left(7 \mathrm{M}^{2}\right)$ equipped with sewing machines such as the ironing machines, fabric cutting machines, buttonhole machines, and machines of making shirts. Facilities and infrastructures are another factor in the learning process of internship. Therefore, the use of the sewing machine is an effective learning tool. Using the tool in the participant's institution or main work setting [16].

Assessment of learning internship or internship evaluation conducted by tutors. Tutors come directly to the place to see the internship learning activities and visit their home. While the facilitator evaluates internship participants through attendance data during internship learning. In addition, facilitators assess levels of proficiency, sewing skills, and product results of stitches. A beginner should be expected to master certain fundamental skills in the training program [17].

Follow-up of apprenticeship in the traditional internship pattern namely internship participants can have the sewing skills and can be implemented at their home. Moreover, postapprenticeship agreement between the internship participants with the facilitator are facilitator gave employment to internship participants for working at home. Those works include to sew shirts, shirts, trousers, school uniforms, and chair slipcovers.

Result and expectation after a post-apprenticeship, trainees have the knowledge, skills and expertise to sew. In addition, they can create jobs, especially in sewing at home each internship participants. Through education and training is expected interwoven synchronization between practice and theory. So that "...education systems are trying to become 
more involved in core skills training and their learning cycles are becoming more connected [18].

The increase in the entrepreneurial community can be seen from three aspects namely: (a) confidence, (b) task-oriented and results, and (c) future-oriented. From the three aspects of the above as follows:

\section{A. Confidence}

The advent of high confidence after following study apprenticeship in confection business such as Participants of the internship ventured to open a business in their own homes. Moreover, internship participants also had confidence that through the tailoring business can meet his family life. Then, the higher confidence of internship participants to obtain orders from customers in large numbers, such as sports shirts, shirts, pants, and chair slipcovers. Through the self-confidence raises optimism high. Because the apprenticeship can exchange information, gain insight sewing, and add relationships in the work.

In apprenticeship, passion for learning is needed such as achievement motivation. With the achievement motivation, trainees will be more enthusiasm to take part in an internship. In addition, it must be supported with the profit-oriented where with the profit-oriented, trainees can produce an employment opportunity that can generate profit.

\section{1) Task-oriented and Result}

Task-oriented and results are not only material, but also non-material. As with post-apprenticeship, participants get jobs in apprenticeship place. As well as gain knowledge of sewing, the skills to make in stitch patterns and mental attitude in managing the confection business through the task orientation and result. In addition to working in the apprenticeship, trainees also receive the ordered items such as to sew chair slipcovers, bags, praying clothes, school uniform in which is done at home internship participants.

\section{2) Future-oriented}

Industrious entrepreneur who have future orientation. With the future orientation, internship participants can grow the confection business from their homes. And through confection business, family needs can be met. In addition, the established cooperation between internship participants and the facilitator in developing the confection business. Through entrepreneurship internship, participants can develop entrepreneurial skills according to their ability. "...30 years of research indicate that there are no personality characteristics that predict who will be a successful entrepreneur. Successful small business owners and entrepreneurs come in every shape, size, color, and from all backgrounds" [19].

Advantages and disadvantages of traditional internship pattern in the confection business are; the advantages (1) on traditional internship pattern, apprenticeship learning method emphasizes practical lesson than on theory with a composition of $80 \%$ on practice and $20 \%$ on theory. According to the facilitator in business activities confection, trainees must be sewed fastly. So that sewing skills quickly is the main capital in confection business. (2) Material apprenticeship in traditional internship pattern is tailored to the needs of internship participants and the needs of the business confection. Therefore, the material internship is applicative and according to the needs of the community. (3) The results and benefits of internship learning, trainees gain knowledge about confection, more modern sewing skills, have the mental attitude of entrepreneurship and insight in the field of business management especially in confection.

Disadvantages of the traditional internship pattern are; (1) the carrying capacity is not optimal like the carrying capacity of the local government is not maximized. For example, sometimes request of the assistance facilities and infrastructures for sewing tools are not realized. (2) The lack of government mentoring on traditional internship pattern activity from the beginning to the end of the learning activities. The local government has not been able to facilitate the internship participants to deliver the results of confection to larger communities.

\section{CONCLUSION}

Implementation of traditional internship pattern in the confection business begins with the identification of the learning needs of the community. Identification of these skills is in accordance with the internship participants, the formulation of the purpose of internship, as well as teaching materials internship in accordance with the needs of the internship. The implementation stage begins with the internship learning activities with internship participants gain knowledge of sewing, sewing skills as well as the mental attitude to entrepreneurship in the business of confection.

The internship assessment phase is to evaluate the learning process of the internship through the effectiveness of trainees in learning activities. And proficiency in receiving material from the internship facilitator. Follow-up of the internship is an agreement stage between trainees and facilitator in the responsibility for the management of an apprenticeship. With the tasks of the facilitators, trainees can master the sewing skills quickly. As well as these skills, can be used to open a tailoring business at their home.

The increase in entrepreneurship community can be seen from the trainees have knowledge of sewing, sewing fast, entrepreneurship mental attitude, and insight in the field of business confection. So they can open business fields to provide for the family.

The advantages traditional internship pattern lies in the practice of teaching methods, so that the trainees learning to be more adept at tailoring. And material the internship adjusted to the needs of trainees. The result of learning the internship, trainees have the sewing skills quickly, and can be developed to improve their confection business. Disadvantages of the traditional internship pattern lack government support and the lack of government mentoring to develop confection business.

\section{ACKNOWLEDGMENT}

The author would like to thank Indonesia Endowment Fund for Education (LPDP) Scholarship, Ministry of Finance of the Republic of Indonesia that has supported this research. 


\section{REFERENCES}

[1] "BPS_ Pengangguran Terbuka di Indonesia Capai 7,02 Juta Orang kesra_tempo.”.

[2] Sistem Pendidikan Nasional. 2003, p. 14.

[3] "Jumlah Penduduk Buta Aksara Capai 81."

[4] K. Probolinggo and P. Jawa, "LKj IP 2015 Kabupaten Probolinggo Provinsi Jawa Timur," p. 21, 2015.

[5] Republik Indonesia, "Peraturan Pemerintah Nomor 31 Tahun 2006," Sist. Pelatih. Kerja Nas., 2006.

[6] M. Rendall and F. J. Weiss, "Employment polarization and the role of the apprenticeship system," Eur. Econ. Rev., vol. 82, pp. 166-186, 2016.

[7] Sugiyono, Metode Penelitian Kuantitatif Kualitatif dan R\&D. Bandung: Alfabeta, 2012.

[8] Y. Riyanto, Metodelogi Penelitian Pendidikan Kualitatif dan Kuantitatif. Surabaya: Unesa University Press, 2007.

[9] L. J. Moleong, Metode Penelitian Kualitatif. Bandung: Remaja Rosda Karya, 2011.

[10] D. Sudjana, Startegi Pembelajaran Partisipatif dalam Pendidikan Luar Sekolah. Bandung: Nusantara Press, 1993.

[11] D. Sudjana, Strategi Pembelajaran. Bandung: Falah Production, 2005.

[12] D. Sudjana, Teknik Analisis Regresi dan Korelasi. Bandung: Tarsito, 1996.

[13] F. Joerin, G. Desthieux, S. B. Beuze, and A. Nembrini, "Participatory diagnosis in urban planning: Proposal for a learning process based on geographical information," J. Environ. Manage., vol. 90, no. 6, pp. 2002-2011, 2009.

[14] "International Journal for Research in Vocational Education and Training," IJRVET, vol. Vol.2, No., no. 1, p. 6, 2015.

[15] K. Gow, C. Hinschen, D. Anthony, and C. Warren, "Work expectations and other factors influencing male apprentices' intentions to quit their trade," Asia Pacific J. Hum. Resour., vol. 46, no. 1, pp. 99-121, 2008.

[16] L. Medina, E. Acosta-Pérez, C. Velez, G. Martínez, M. Rivera, L. Sardiñas, and a Pattatucci, "Training and capacity building evaluation: Maximizing resources and results with Success Case Method.," Eval. Program Plann., vol. 52, pp. 126-32, 2015.

[17] J. Cissik, "Basic principles of strength training and conditioning," NSCA's Perform. Train. J., vol. 1, no. 4, pp. 7-11, 2002.

[18] A. Neghavati, "Core Skills Training in a Teacher Training Programme," Procedia - Soc. Behav. Sci., vol. 232, no. April, pp. 617-622, 2016.

[19] R. A. Baron, "Cognitive mechanisms in entrepreneurship: Why and when enterpreneurs think differently than other people," J. Bus. Ventur. vol. 13, no. 4, pp. 275-294, 1998. 